\title{
Estimation of Postmortem Interval from mRNA Degradation and Autolytic Changes in the Brain and Adrenal Gland
}

\author{
Dalia Mohamed Ali ${ }^{1}$, Osama A. Hassan ${ }^{1}$, Maggie M. Ramzy ${ }^{2}$, Nagwa M. Zenhom ${ }^{2}$
}

\begin{tabular}{|c|c|}
\hline & ABSTRACT \\
\hline $\begin{array}{l}\text { KEYWORDS } \\
\text { Postmortem, } \\
\text { Brain, } \\
\text { Adrenal gland, } \\
\text { mRNA, } \\
\text { caspase- } 3 \text {, } \\
\text { IL-1 } \beta\end{array}$ & 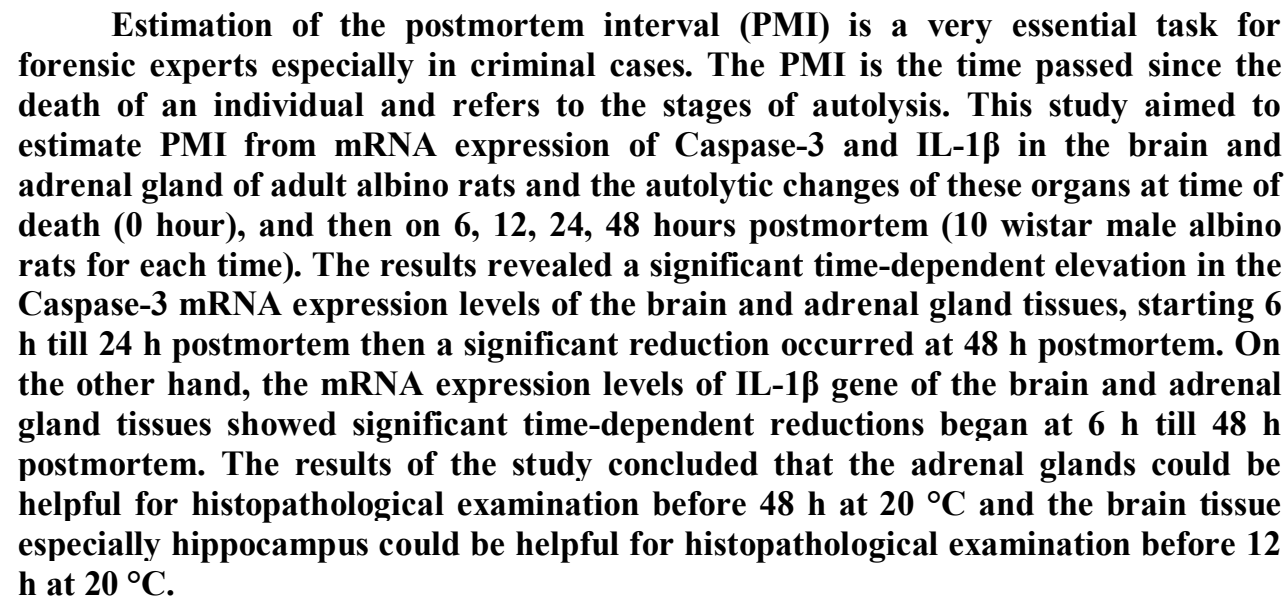 \\
\hline
\end{tabular}

\section{Introduction}

The postmortem interval (PMI) is the time passed since the death of a human and refers to the stages of autolysis. Vass et al. (2002) have divided PMI to; early PMI (first 72 $\mathrm{h}$ postmortem) and late PMI (more than 3 days postmortem). The decomposition of the body organs has been affected by several factors. A large water content (spleen), a high concentration of lytic enzymes (adrenal gland, pancreas), a low conjunctive matrix (heart, brain, lungs), and bathing in corrosive liquids

\footnotetext{
(1) Forensic Medicine and Toxicology Department, Faculty of Medicine-Minia University, Egypt

(2) Biochemistry Department, Faculty of Medicine-Minia University, Egypt
}

(stomach) increase the speed of autolytic processes (Hostiuc et al., 2017).

Accurate determination of the PMI is an important focal point of examination in criminal and forensic sciences to reveal the circumstances of death. There are variable methods for estimation of the time of death (physical (algor mortis, livor mortis), physicochemical (rigor mortis), biochemical (electrolyte concentrations, enzyme activity), microbiological

(decomposition), entomological and botanical processes) (Henssge \& Madea, 2007). There are numerous factors affect the accuracy of these methods (such as environmental temperature and humidity, body structure and pathologies, etiology of death, or putative drug consumption) (Prahlow, 2010). 
New techniques such as ultrastructure methods, flow cytometry, magnetic resonance spectroscopy and capillary zone electrophoresis have been suggested to estimate PMI. While these methods do not determine death time exactly, use of more than one method has been recommended to decrease the associated errors (Madea, 2005). The parameters that change regularly with time after death give perfect assessment of the PMI. Recently, post mortem degradation of RNA plays a key role in forensic sciences as a rapid and time-dependent indicator of PMI (Gomaa et al., 2013). After death, RNA undergoes degradation by ribonucleases; either from the cell, released from bacteria or other environmental corruption (Sampaio-Silva et al., 2013).

Real-time quantitative polymerase chain reaction (qRT-PCR) is considered a potent technique for the detection and quantification of mRNA because it is a highly sensitive and reproducible method and has wide range for quantification of the nucleic acid (Pfaffl, 2004). Many researchers have studied different mRNA markers in different body organs for estimation of postmortem interval (WenCan et al., 2014; Lv et al., 2016). Owed to few postmortem interval studies included the adrenal gland (Monoranu et al., 2009), the purpose of this study was to estimate PMI from mRNA expression of caspase- 3 and IL- $1 \beta$ in the brain and adrenal gland of adult albino rats and the autolytic changes of these organs.

\section{Material and Methods}

Fifty wistar male albino rats weighting 200-220 gm were obtained from Minia University Laboratory Animals Growing Center-Egypt. The animals were kept in their cages with free access to tap water and standard rodent chow at a laboratory temperature of $20^{\circ} \mathrm{C}$ through the experiment.
Animals and their care were done consistent with the local guidelines of Animal Care Ethical Committee of Faculty of Medicine, Minia University, Egypt.

The animals were anesthetized with ether then sacrificed by cervical dislocation. The rats were divided into equal five groups according to the postmortem time interval (at $0,6,12,24$, 48 hour postmortem). The brain and adrenal glands were dissected and removed as a whole organ at each time.

\section{Real-time reverse transcription polymerase chain reaction for the relative quantification of caspase-3 and IL-1及}

Extraction of total RNA from homogenized brain and adrenal specimen using ribozol RNA extraction reagent (Amresco, Solon, USA) was done following the manufacturer's instructions. Revert Aid ${ }^{\mathrm{TM}}$ First Strand cDNA Synthesis kit (Fermentas, Life Sciences) was used for synthesis of cDNAs then reverse transcription followed by direct cooling on ice. Usage of $25 \mu \mathrm{L}$ of SYBR Green QPCR Mix (Solis BioDyne) containing $20 \mu \mathrm{M}$ of specific primers in the Real-Time PCR Detection System with $50 \mathrm{ng}$ cDNA per reaction was used. Analysis with a relative quantification to GAPDH (Glyceraldehyde-3phosphate dehydrogenase) as reference gene for the SYBR green data was done. The sets of primers used were as follows:

Caspase3 sense primers, 5'TACCCTGAAATGGGCTTGTGT - $3^{\prime}$, and caspase3 antisense, $5^{\prime}-$ GTTAACACGAGTGAGGATGTG -3'

IL-1 $\beta \quad$ sense primers; 5'GCACTACAGGCTCCGAGATGAAC $-3^{\prime}$ and antisense $5^{\prime}$ TTGTCGTTGCTTGGTTCTCCTTGT $-3^{\prime}$ and GAPDH sense primers: 5' GTCGGTGTGAACGGATTTG3' and 
antisense

\section{CTTGCCGTGGGTAGAGTCAT3'.}

The relative expression level of each gene was calculated using the formula $2^{(-\Delta \Delta \mathrm{Ct})}$ according to Van Guilder et al. (2008). The results were presented as relative expression compared with the control where the control samples were set at a value of 1 .

\section{Histopathological study}

Brain and adrenal gland tissue specimens were fixed in $10 \%$ neutral buffered formalin, then trimming was done. Ascending grades of alcohol were used for washing and dehydration, cleared in xylene, embedded in paraffin, and sectioned at 4-6U thickness. Finally, staining by hematoxylin and eosin was done according to Bancroft et al. (2008).

Histological evaluation of the autolytic changes in cerebellar granule cell layer: the degree of autolytic degradation was determined microscopically by assessment of the granular cell layer of the cerebellum as nil, mild, moderate or severe according to Sheedy et al. (2012). Nil means: no anomaly was detected; mild: there is a minimal reduction in the nuclei number; moderate: there is a widespread reduction in the nuclei number while a number of nuclei are still obviously visible and severe: minimal or no visible nuclei and there is vacuolation of the granule cell layer.

\section{Statistical Analysis:}

The collected data were coded, tabulated, and statistically analyzed using SPSS program (Statistical Package for Social Sciences) software version 25 .

Parametric quantitative data underwent descriptive statistics by mean, standard deviation and minimum \& maximum of the range, on the other side, the categorical data underwent descriptive statistics by number and percentage.

Analyses were done for parametric quantitative data between the different groups using One-way ANOVA test followed by post hoc Tukey analysis.

Independent samples $\mathrm{T}$ test were used for analyses of parametric quantitative data between the two groups, while Mann Whitney test were used for nonparametric quantitative data between the two groups.

Correlation between the time passed since death and the two gene expressions using Pearson's correlation coefficient followed by linear regression analysis.

The level of the significance was taken at ( $\mathrm{p}$ value $<0.05)$.

\section{Results}

Real-time reverse transcription polymerase chain reaction for the relative quantification of caspase- 3 and $I L-1 \beta$

Caspase-3 shows a significant timedependent elevation in the relative mRNA expression levels of the brain (Table 1) and adrenal gland tissues (Table 2), starting six hrs till $24 \mathrm{hrs}$ postmortem then a significant reduction occurred at $48 \mathrm{hrs}$ postmortem (Figure 1).

On the other hand, the relative mRNA expression levels of IL-1 $\beta$ gene of the brain (Table 3) and adrenal gland tissues (Table 4) show significant time-dependent reductions began at $6 \mathrm{hrs}$ till $48 \mathrm{hrs}$ postmortem. (Figure 2)

The results of relative mRNA expression levels were correlated with the postmortem period. Table (5) shows significant moderate 
positive linear correlations of the brain and adrenal gland relative mRNA expression levels of caspase-3 with the postmortem period (Figure 3). While, brain and adrenal gland mRNA expression levels of IL- $1 \beta$ show a significant strong negative linear correlation with the postmortem period (Table 6) (Figure 4).
Table (7) and (8) provide the regression formulae for relative mRNA expression levels of caspase- 3 and IL- $1 \beta$ in brain and adrenal gland. Relative mRNA expression levels of IL$1 \beta$ show higher accuracy for estimation of time passed since death $(\mathrm{R} 2=0.850 \& 0.771)$, than mRNA expression levels of caspase-3 (R2 $=0.446 \& 0.428)$ in both brain and adrenal gland tissues respectively.

Table (1): One-way ANOVA statistical analysis of brain caspase-3 at different times postmortem.

\begin{tabular}{|c|c|c|c|c|c|c|}
\hline \multirow[t]{3}{*}{$\begin{array}{l}\text { Brain } \\
\text { Caspase-3 }\end{array}$} & $\begin{array}{c}0 \text { h PM } \\
(n=10)\end{array}$ & $\begin{array}{c}6 \text { h PM } \\
(n=10)\end{array}$ & $\begin{array}{c}12 \text { h PM } \\
(n=10)\end{array}$ & $\begin{array}{c}24 \text { h PM } \\
(n=10)\end{array}$ & $\begin{array}{c}48 \text { h PM } \\
(n=10)\end{array}$ & $\begin{array}{l}\text { p value } \\
\text { ANOVA }\end{array}$ \\
\hline & $(1-1)$ & $(1.2-1.3)$ & $(1.4-1.4)$ & $(1.7-1.8)$ & $(1.6-1.7)$ & \multirow{2}{*}{$<0.001^{*}$} \\
\hline & $1 \pm 0$ & $1.3 \pm 0.03$ & $1.4 \pm 0.03$ & $1.8 \pm 0.04$ & $1.6 \pm 0.03$ & \\
\hline \multicolumn{7}{|c|}{ p value (post hoc test) } \\
\hline $\mathbf{0 ~ h}$ & & $<0.001^{*}$ & $<0.001^{*}$ & $<0.001 *$ & $<0.001^{*}$ & \\
\hline $6 \mathrm{~h}$ & & & $<0.001^{*}$ & $<0.001 *$ & $<0.001^{*}$ & \\
\hline $12 \mathrm{~h}$ & & & & $<0.001 *$ & $<0.001^{*}$ & \\
\hline $24 \mathrm{~h}$ & & & & & $<0.001 *$ & \\
\hline
\end{tabular}

Data expressed by range, mean \pm SD (Standard deviation); One-way ANOVA test followed by post hoc Tukey analysis; *: significant; PM: postmortem

Table (2): One-way ANOVA statistical analysis of adrenal gland caspase-3 at different times postmortem.

\begin{tabular}{|c|c|c|c|c|c|c|}
\hline \multirow{3}{*}{$\begin{array}{l}\text { Adrenal } \\
\text { Caspase } 3\end{array}$} & $\begin{array}{c}0 \text { h PM } \\
(n=10)\end{array}$ & $\begin{array}{c}6 \text { h PM } \\
(n=10)\end{array}$ & $\begin{array}{c}12 \text { h PM } \\
(n=10)\end{array}$ & $\begin{array}{c}24 \text { h PM } \\
(n=10)\end{array}$ & $\begin{array}{c}48 \text { h PM } \\
(n=10)\end{array}$ & $\begin{array}{l}\text { p value } \\
\text { ANOVA }\end{array}$ \\
\hline & $(1-1)$ & $(2.1-2.2)$ & $(2.3-2.4)$ & $(2.6-2.7)$ & $(2.4-2.6)$ & \multirow{2}{*}{$<0.001^{*}$} \\
\hline & $1 \pm 0$ & $2.2 \pm 0.04$ & $2.3 \pm 0.03$ & $2.6 \pm 0.03$ & $2.5 \pm 0.04$ & \\
\hline \multicolumn{7}{|c|}{ p value (post hoc test) } \\
\hline $\mathbf{0 h}$ & & $<0.001^{*}$ & $<0.001^{*}$ & $<0.001^{*}$ & $<0.001^{*}$ & \\
\hline $6 \mathrm{~h}$ & & & $<0.001^{*}$ & $<0.001^{*}$ & $<0.001^{*}$ & \\
\hline $12 \mathrm{~h}$ & & & & $<0.001 *$ & $<0.001^{*}$ & \\
\hline $24 \mathrm{~h}$ & & & & & $<0.001^{*}$ & \\
\hline
\end{tabular}

Data expressed by range, mean \pm SD (Standard deviation); One-way ANOVA test followed by post hoc Tukey analysis; *: significant; PM: postmortem 
Table (3): One-way ANOVA statistical analysis of brain IL-1 $\beta$ at different times postmortem.

\begin{tabular}{|c|c|c|c|c|c|c|}
\hline \multirow{3}{*}{ Brain IL-1及 } & $\begin{array}{c}0 \text { h PM } \\
(n=10)\end{array}$ & $\begin{array}{c}6 \text { h PM } \\
(n=10)\end{array}$ & $\begin{array}{c}12 \text { h PM } \\
(n=10)\end{array}$ & $\begin{array}{c}24 \text { h PM } \\
(n=10)\end{array}$ & $\begin{array}{c}48 \text { h PM } \\
(n=10)\end{array}$ & $\begin{array}{l}\text { p value } \\
\text { ANOVA }\end{array}$ \\
\hline & $(1-1)$ & $(23.2-28.1)$ & $(18.4-19.9)$ & $(13.5-14.5)$ & $(9.2-11.1)$ & \multirow{2}{*}{$<0.001 *$} \\
\hline & $1 \pm 0$ & $25 \pm 1.48$ & $19.1 \pm 0.46$ & $14 \pm 0.35$ & $10 \pm 0.61$ & \\
\hline \multicolumn{7}{|c|}{ p value (post hoc test) } \\
\hline$\overline{\mathbf{O h}}$ & & $<0.001^{*}$ & $<0.001^{*}$ & $<0.001^{*}$ & $<0.001^{*}$ & \\
\hline $6 \mathrm{~h}$ & & & $<0.001 *$ & $<0.001 *$ & $<0.001^{*}$ & \\
\hline $12 \mathrm{~h}$ & & & & $<0.001^{*}$ & $<0.001^{*}$ & \\
\hline $24 \mathrm{~h}$ & & & & & $<0.001^{*}$ & \\
\hline
\end{tabular}

Data expressed by range, mean \pm SD (Standard deviation); One-way ANOVA test followed by post hoc Tukey analysis;

*: significant; PM: postmortem

Table (4): One-way ANOVA statistical analysis of adrenal IL-1 $\beta$ at different times postmortem.

\begin{tabular}{|c|c|c|c|c|c|c|}
\hline \multirow{3}{*}{ Adrenal IL-1及 } & $\begin{array}{l}0 \text { h PM } \\
(n=10)\end{array}$ & $\begin{array}{l}6 \mathrm{~h} P M \\
(\mathrm{n}=10)\end{array}$ & $\begin{array}{c}12 \text { h PM } \\
(n=10)\end{array}$ & $\begin{array}{c}24 \text { h PM } \\
(n=10)\end{array}$ & $\begin{array}{c}48 \text { h PM } \\
(n=10)\end{array}$ & $\begin{array}{l}\text { p value } \\
\text { ANOVA }\end{array}$ \\
\hline & $(1-1)$ & $(88.8-91.2)$ & $(79.4-81.2)$ & $(74.5-75.7)$ & $(70.1-72.2)$ & \multirow{2}{*}{$<0.001 *$} \\
\hline & $1 \pm 0$ & $90 \pm 0.78$ & $80.1 \pm 0.61$ & $75 \pm 0.40$ & $71 \pm 0.73$ & \\
\hline \multicolumn{7}{|c|}{ p value (post hoc test) } \\
\hline $\mathbf{0 ~ h}$ & & $<0.001^{*}$ & $<0.001^{*}$ & $<0.001^{*}$ & $<0.001^{*}$ & \\
\hline $6 \mathrm{~h}$ & & & $<0.001^{*}$ & $<0.001^{*}$ & $<0.001^{*}$ & \\
\hline $12 \mathrm{~h}$ & & & & $<0.001^{*}$ & $<0.001^{*}$ & \\
\hline $24 \mathrm{~h}$ & & & & & $<0.001^{*}$ & \\
\hline
\end{tabular}

Data expressed by range, mean \pm SD (Standard deviation); One-way ANOVA test followed by post hoc Tukey analysis;

*: Significant; PM: postmortem

Table (5): Pearson's correlation between the postmortem interval and relative mRNA expression levels of caspase- 3 and IL-1 $\beta$ genes in the brain tissue.

\begin{tabular}{|l|c|c|}
\hline \multirow{2}{*}{ Brain } & \multicolumn{2}{|c|}{ Time } \\
\cline { 2 - 3 } & $\mathbf{2}$ & p value \\
\hline caspase & 0.668 & $<0.001^{*}$ \\
\hline IL-1 & -0.922 & $<0.001 *$ \\
\hline
\end{tabular}

* Significant. 
Table (6): Pearson's correlation between the postmortem interval and relative mRNA expression levels of caspase- 3 and IL-1 $\beta$ genes in the adrenal gland tissue.

\begin{tabular}{|l|c|c|}
\hline \multirow{2}{*}{ Adrenal gland } & \multicolumn{2}{|c|}{ Time } \\
\cline { 2 - 3 } & $\mathbf{r}$ & p value \\
\hline Caspase & 0.654 & $<0.001^{*}$ \\
\hline IL-1 $\beta$ & -0.878 & $<0.001^{*}$ \\
\hline
\end{tabular}

* Significant.

Table (7): Simple linear regression analysis of relative mRNA expression levels of caspase-3 and IL-1 $\beta$ genes in the brain tissue.

\begin{tabular}{|c|c|c|c|c|c|c|c|}
\hline \multirow{2}{*}{ Brain } & \multicolumn{2}{|c|}{$\begin{array}{l}\text { Unstandardized } \\
\text { Coefficients }\end{array}$} & \multirow{2}{*}{ p value } & \multirow{2}{*}{$\mathbf{R}$} & \multirow{2}{*}{$\mathbf{R}^{2}$} & \multirow{2}{*}{ SEE } & \multirow{2}{*}{ Regression equation } \\
\hline & B & $\begin{array}{l}\text { Std. } \\
\text { error }\end{array}$ & & & & & \\
\hline $\begin{array}{l}\text { Caspase } \\
\text { Constant }\end{array}$ & $\begin{array}{l}55.4 \\
-60.8\end{array}$ & $\begin{array}{c}10 \\
15.2\end{array}$ & $\begin{array}{l}<0.001^{*} \\
<0.001^{*}\end{array}$ & 0.668 & 0.446 & 12.3 & $\mathrm{~T}=-60.8+(55.4 \times \mathrm{CS} 3)$ \\
\hline 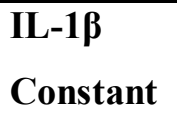 & $\begin{array}{c}-2.6 \\
67\end{array}$ & $\begin{array}{l}0.2 \\
3.2\end{array}$ & $\begin{array}{l}<0.001^{*} \\
<0.001^{*}\end{array}$ & 0.922 & 0.850 & 6.4 & $\mathrm{~T}=67+(-2.6 \times \mathrm{IL}-1 \mathrm{~B})$ \\
\hline
\end{tabular}

* Significant

Table (8): Simple linear regression analysis of relative mRNA expression levels of caspase-3 and IL- $1 \beta$ genes in the adrenal gland tissue.

\begin{tabular}{|c|c|c|c|c|c|c|c|}
\hline \multirow{2}{*}{$\begin{array}{c}\text { Adrenal } \\
\text { gland }\end{array}$} & \multicolumn{2}{|c|}{$\begin{array}{l}\text { Unstandardized } \\
\text { Coefficients }\end{array}$} & \multirow{2}{*}{ p value } & \multirow{2}{*}{$\mathbf{R}$} & \multirow{2}{*}{$\mathbf{R}^{2}$} & \multirow{2}{*}{ SEE } & \multirow{2}{*}{ Regression equation } \\
\hline & B & $\begin{array}{l}\text { Std. } \\
\text { error }\end{array}$ & & & & & \\
\hline $\begin{array}{l}\text { Caspase } \\
\text { Constant }\end{array}$ & $\begin{array}{c}66 \\
-136.3\end{array}$ & $\begin{array}{l}12.4 \\
29.9\end{array}$ & $\begin{array}{l}<0.001 * \\
<0.001 *\end{array}$ & 0.654 & 0.428 & 12.5 & $\mathrm{~T}=-136.3+(66 \times \mathrm{CS} 3)$ \\
\hline 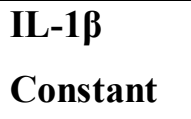 & $\begin{array}{c}-2 \\
178.8\end{array}$ & $\begin{array}{c}0.2 \\
13.9\end{array}$ & $\begin{array}{l}<0.001 * \\
<0.001 *\end{array}$ & 0.878 & 0.771 & 7.9 & $\mathrm{~T}=178.8+(-2 \times \mathrm{IL}-1 \mathrm{~B})$ \\
\hline
\end{tabular}

* Significant. 


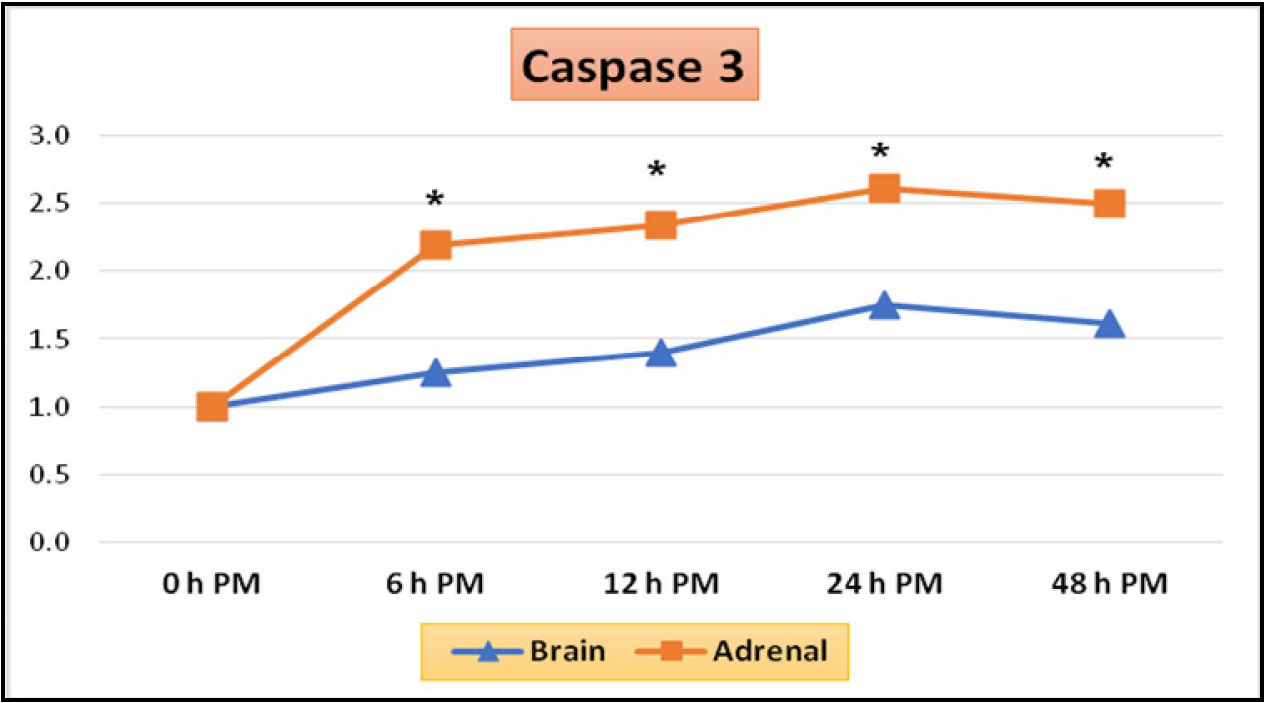

Fig. (1): Relationship between the postmortem period (from 0 to $48 \mathrm{hrs}$ ) and relative mRNA expression levels of caspase-3 in the brain and adrenal gland tissues from the dead rats by RT-PCR.

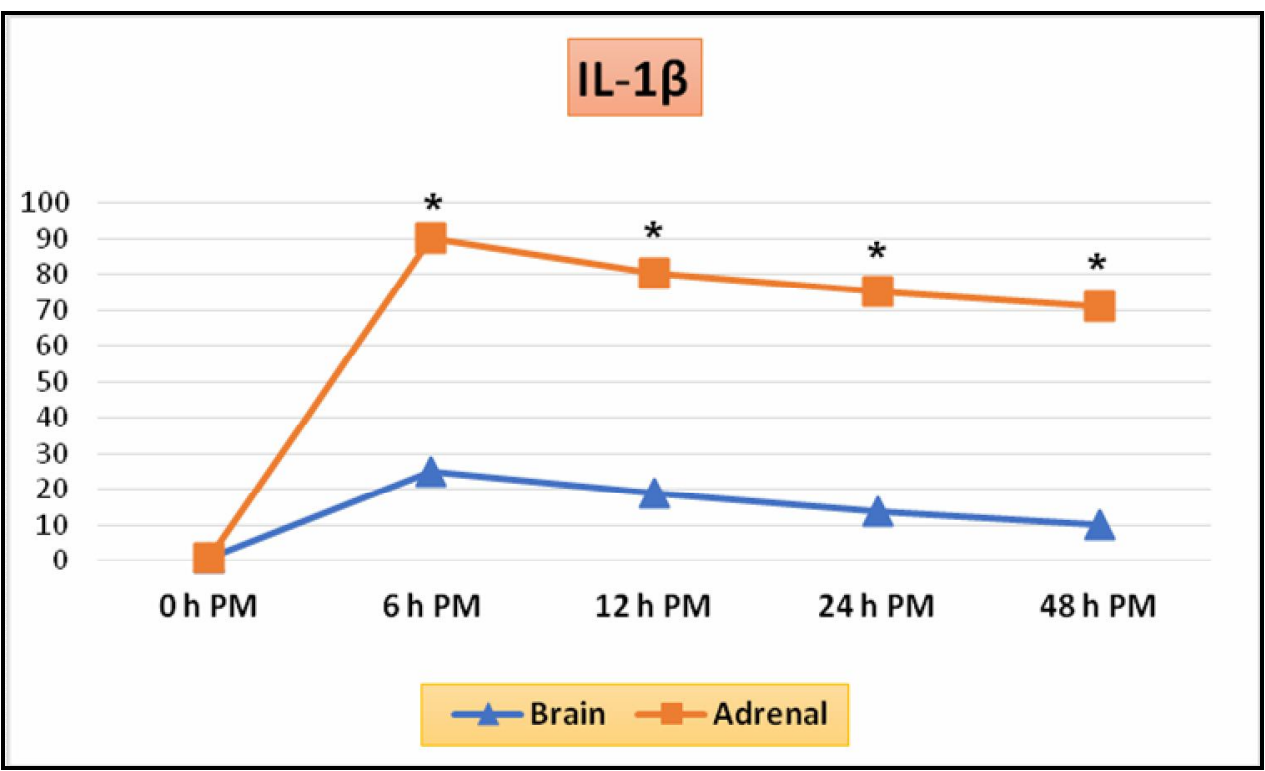

Fig. (2): Relationship between the postmortem period (from 0 to $48 \mathrm{hrs}$ ) and relative mRNA expression level of IL- $1 \beta$ in the brain and adrenal gland tissues from the dead rats by RT-PCR. 


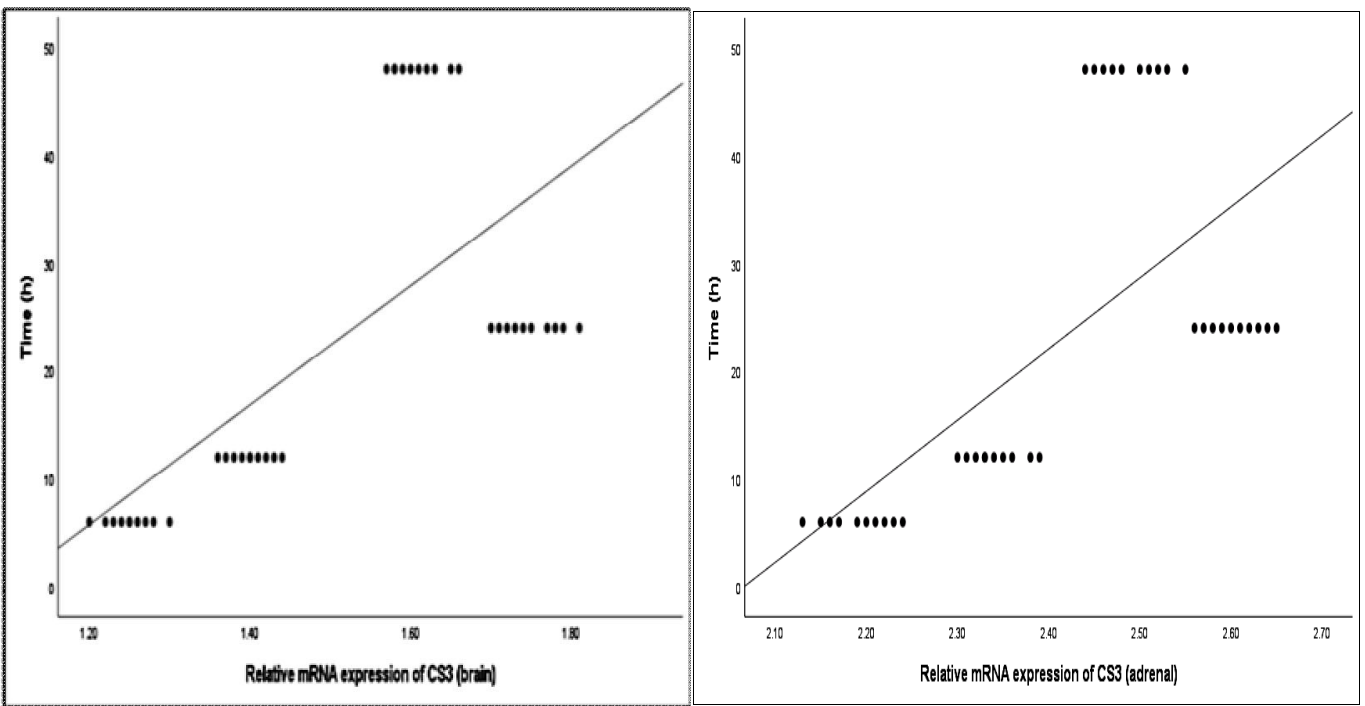

Fig. (3): Correlations between relative mRNA expression levels of Caspase-3 in the brain and adrenal gland and the postmortem period (from $0 \mathrm{hr}$ to 48 hrs). The regression plot: $y$ time, $x$ mRNA expression of caspase-3. A moderate positive linear correlation with the postmortem period was revealed.
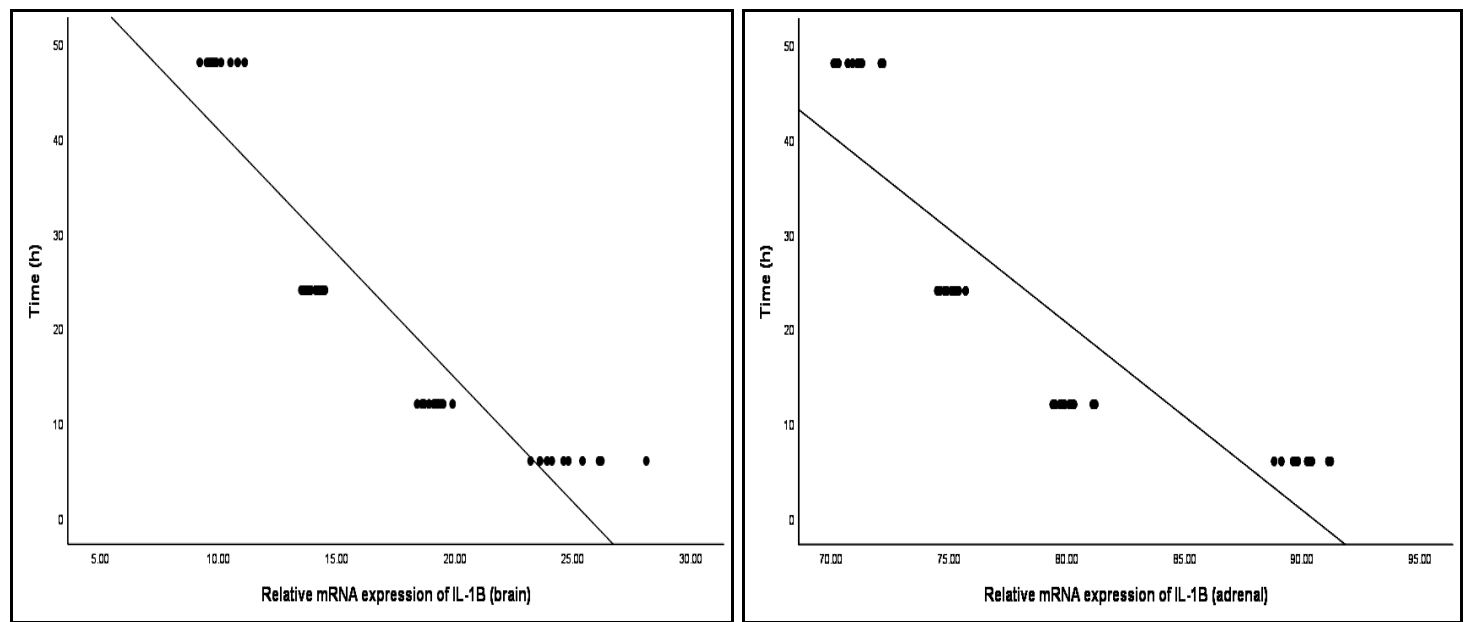

Fig. (4): Correlations between relative mRNA expression levels of IL-1 $\beta$ in the brain and adrenal gland tissues and the postmortem period (from $0 \mathrm{hr}$ to $48 \mathrm{hrs}$ ). The regression plot: y time, x mRNA expression of IL-1B. A strong negative linear correlation with the postmortem period was revealed. 


\section{Histopathological study}

Adrenal gland

Routine staining with $\mathrm{H} \& \mathrm{E}$ of the adrenal gland at $\left(\begin{array}{ll}0 & \mathrm{~h}\end{array}\right)$ showed normal histological structure of well differentiated cortex and medulla (Figure 5-a). The cortex showed three zones; zona granulosa ( $\mathrm{ZG}$ ), zona fasciculata $(\mathrm{ZF})$, and zona reticularis (ZR). Zona granulosa had normal epithelium that showed intact basement membrane, complete hyperchromatic nuclei and the cytoplasm appeared deeply basophilic and eosinophilic (Figure 5-b). Zona fasciculata (ZF) and (ZR) with normal non-dilated sinusoids that showed outstanding endothelial cells (Figure 5-c). Medulla (M) was differentiated from the cortex and had well demarcation.

At (6 hrs) postmortem, architecture was a little normal, and the cortex and the medulla were differentiated from each other (Figure 6a). The intact cellular structure showed with mild swelling (Figure 6-b). Blood sinusoids were mildly dilated (Figure 6-c).

At $(12 \mathrm{~h})$ postmortem, an obvious expansion was observed (Figure 7-a). The cortical three zones were not clearly demarcated with vacuolated cytoplasm (Figure 7-b). Most of the nuclei had condensed nuclear chromatin. Moderate dilatation with minimal sloughed endothelial cells appeared in the blood sinusoids (Figure 7-c). Postmortem changes appeared in the medullary cells before the cortical cells. The medullary cellss nuclei reduced in size, with clumping of the chromatin resulted in pyknosis. Pyknotic nuclei were diffused at the medullary region. Unclear cellular outline of the medulla was observed.

With increasing the postmortem period, at $(24 \mathrm{~h})$ expansion of the cortex and decreasing of the medulla were obvious (Figure $8-a)$. The cells of the cortical three zones were not demarcated and disorganized with deeply basophilic pyknotic nuclei appeared in few cells (Figure 8-b). Severe dilatation with a complete sloughed endothelial cells appeared in the blood sinusoids at the medullary region (Figure 8-c).

At (48 h), irregular capsular outline of the adrenal tissue was noticed (Figure 9-a). The cells of the three cortical zones became variable in shape and size (Figure 9-b). Vacuolated cytoplasm, shrinked and dissociated cells, and lastly karyolysis were seen. A margination of the nuclear chromatin, and reduction of the nuclear size with few nuclear fading were observed at the cortical region, then pyknosis and karyolysis appeared. Karyorrhexis was not a clear characteristic of the cortical and medullary cells. Pale cytoplasm with fragmented nuclear materials appeared at the cells of the three zones. The medullary cells showed foamy pale cytoplasm. The blood sinusoids, which included collated blood, finally ruptured (Figure 9-c). Acidophilic cytoplasm with widespread dissociated cells was seen.

Brain

Routine staining with H\&E of the brain tissue showed no noticeable histological changes of the brain at $(0 \mathrm{~h})$ (Figure 10 -a) with no evidence of nuclear breakdown (Figure 10b). No morphological anomaly was seen with obvious granular cell nuclei (grade: nil) (Figure $10-c)$.

The earliest postmortem changes, found at $(6 \mathrm{~h})$, the central folia showed granular autolytic layers beside the central white medullary body of the cerebellum (Figure 11a). Granular cell layer of hippocampus showed mild decrease in number (Grade: mild) (Figure 11-b). The pyramidal cell layer in the hippocampus revealed pale stain affinity with ill-defined nuclear detail (Figure 11-c).

On the other hand, at (12 h), dispersion of granular cell layer was seen (Figure 12-a). Tigrolysis in Purkinje cells and pyramidal cells 
in the hippocampus was noticed. No hyperchromatosis or pyknotic neurons were noticed (Figure 12-b). Loss of the nuclei and diffuse pallor were observed. Figure (12-c) showed small and mature neurons and oligodendrocytes with no significant histopathological changes (grade: moderate)

At $24 \mathrm{hrs}$, a reduction of the granular cell layer number was observed (Figure 13-a). Autolysis of cells with nucleolar pyknotic nuclei became apparent and spread toward the peripheral folia, and finally to the cerebellar cortex (Figure 13-b). Multiple changes such as contractile eosinophilic cytoplasm with blurred dark, pale or pyknotic nuclei were seen in the purkinje cells (grade: moderate) (Figure $13-c)$.

At (48 hrs), hippocampus showed distinct reduction of granular cells number and size with intercellular oedema (Figure 14-a). Autolytic changes were clearly seen in the form of pyramidal cell layer lysis which appeared as basophilic bodies (Figure 14-b). One or two intact granular layers appeared sporadically with very small patches in the severely autolytic cerebellum (grade: severe) (Figure $14-c)$.

Fig. (5): Photomicrograph of adrenal tissue section at 0hs showing: (a) Normal histological structure with well differentiated cortex and medulla [x100]. (b) Normal epithelium with intact basement membrane of zona granulosa (arrow) [x400]. (c) Zona fasciculata and zona reticularis showing normal non-dilated sinusoids (arrow) [x400].

Fig. (6): Photomicrograph of adrenal tissue section at 6hs showing: (a) Slightly maintained architecture, and well differentiated cortex and medulla [x100]. (b) Mild swelling in both cortex and medulla cells (arrow) [x400] (c) Dilatation of blood sinusoids (arrow) [x400]. 


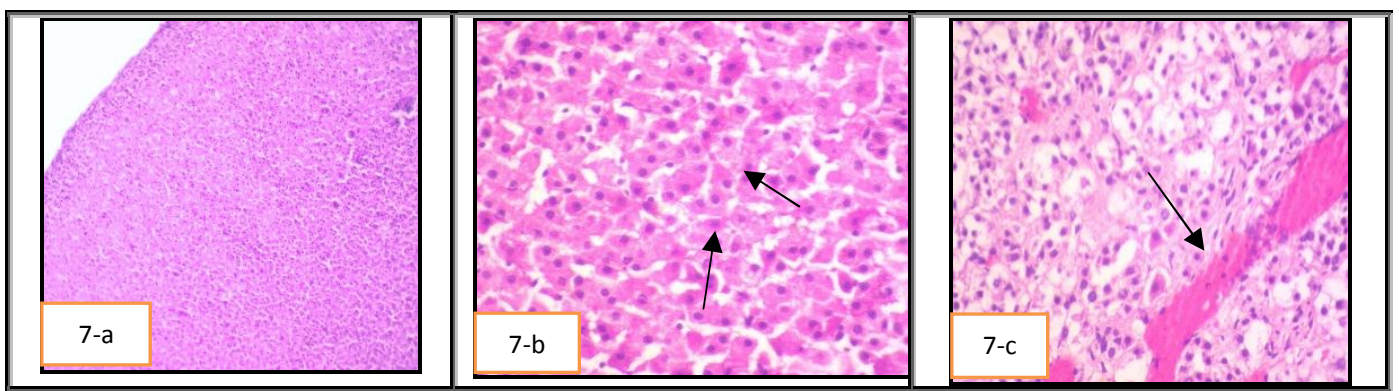

Fig. (7): Photomicrograph of adrenal tissue section at 12hs showing: (a) A marked expansion of adrenal gland [x100] (b) Cellular outline of ZG, ZF and ZR was not clear [x400]. (c) Moderate dilatation of sinusoids [x400].

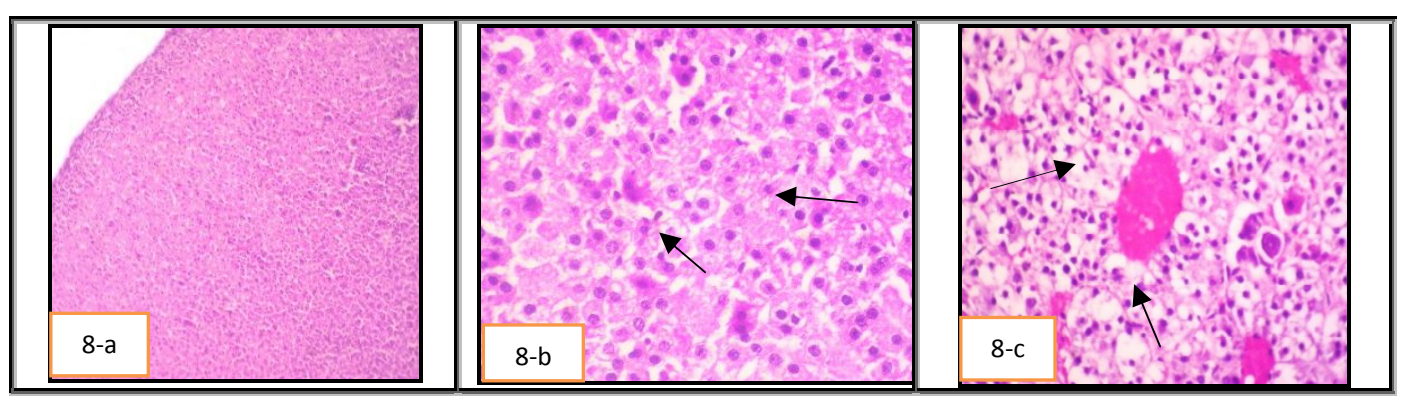

Fig. (8): Photomicrograph of adrenal tissue section at 24hs showing: (a) Expansion of cortical region and reduction of medulla[x100] (b) The cellular outline of ZG, $\mathrm{ZF}$ and ZR have no demarcation (arrow) [x400]. (c) Severe dilatation of blood sinusoids (arrow) [x400].

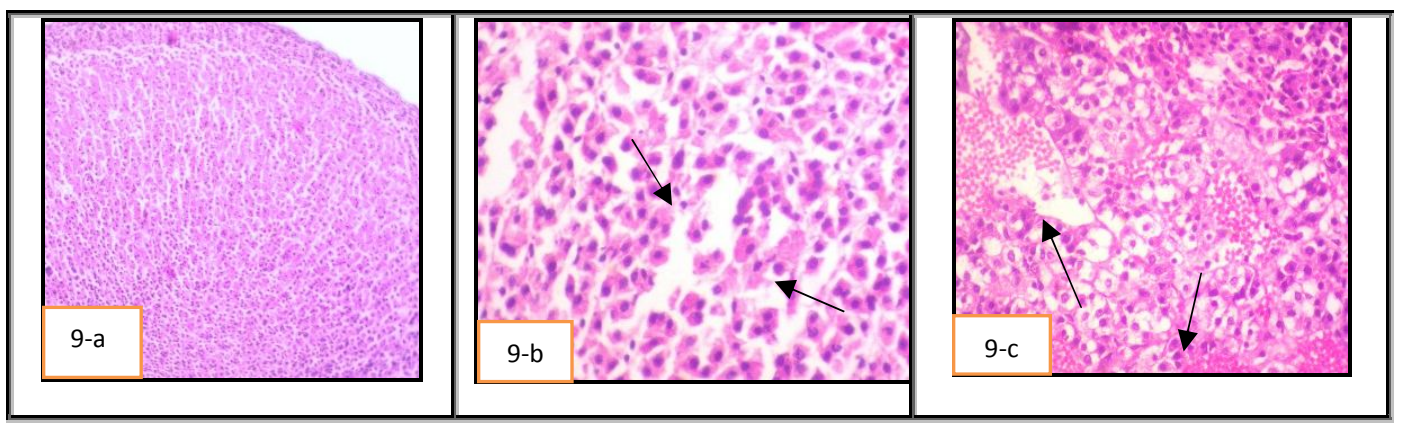

Fig. (9): Photomicrograph of adrenal tissue section at 48hs showing: (a) Irregularity of capsular outline [x100] (b) Hazard arrangement of ZG, ZF and ZR cells which have different shape and size (arrow) [x400]. (c) Rupture of blood sinusoids (arrow). [x400] (H\&E) 

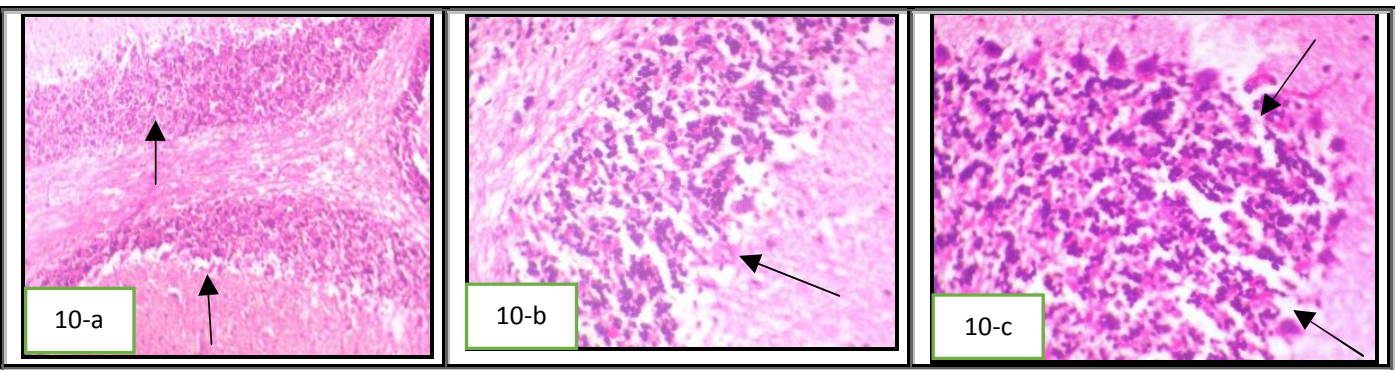

Fig. (10): Photomicrograph of hippocampus tissue section at 0hs showing: (a) No appreciable histologic changes of hippocampal neurons (arrow) [x100] (b) No evidence of nuclear breakdown (arrow) [x200] (c) Granular cells nuclei were clearly visible (arrow). [x400]
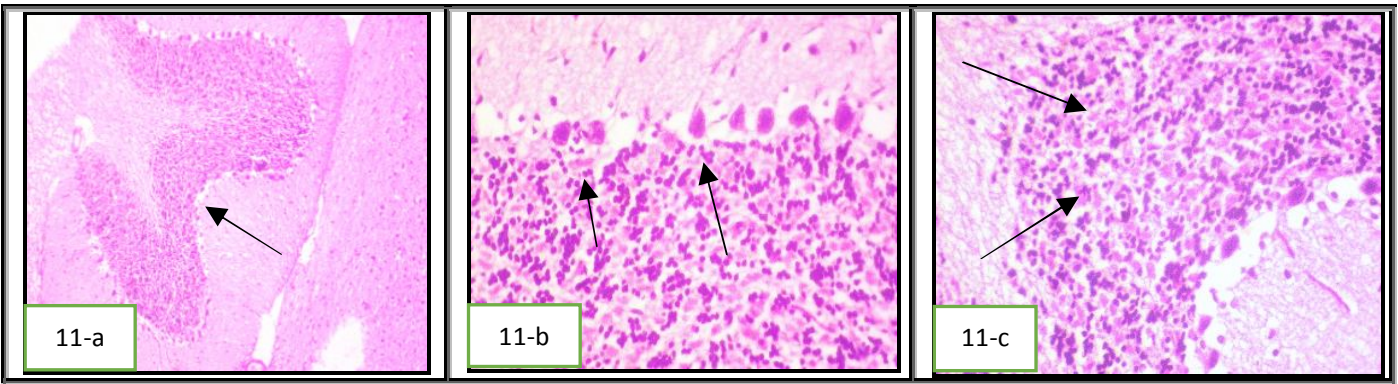

Fig. (11): Photomicrograph of hippocampus tissue section at 6hs showing: (a) Granular autolytic layers appeared only in the central folia (arrow) [x100] (b) Granular cell layer of hippocampus showed mild decrease in number (arrow) [x200] (c) The pyramidal cell layer has pale stain affinity with ill-defined nuclear detail (arrow) [x400].
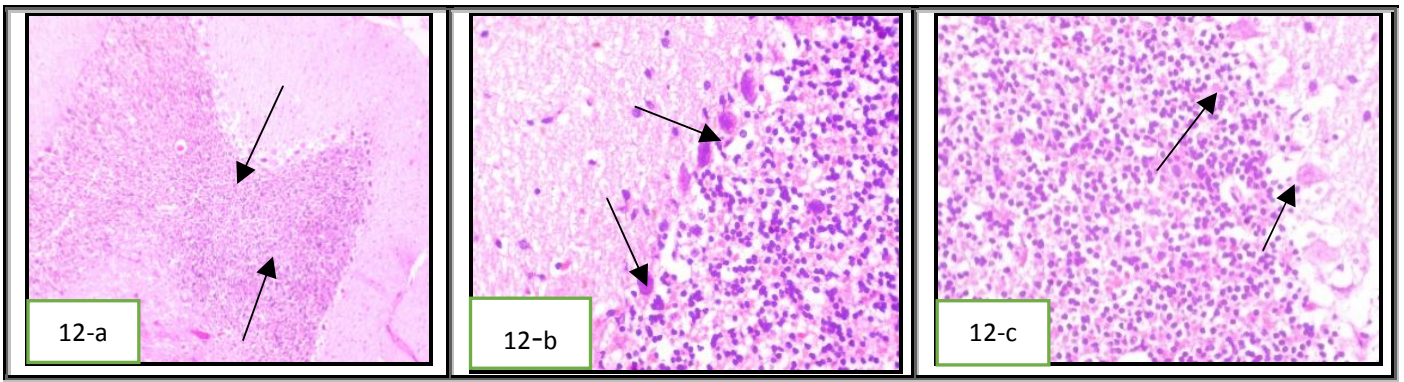

Fig. (12): Photomicrograph of hippocampus tissue section at $12 \mathrm{hs}$ showing: Dispersion of granular cell layer (arrow) [x100] (b)Tigrolysis in Purkinje cells and pyramidal cells in the hippocampus (arrow) [x200] (c) Loss of the nuclei and diffuse pallor (arrow) [x400]. 

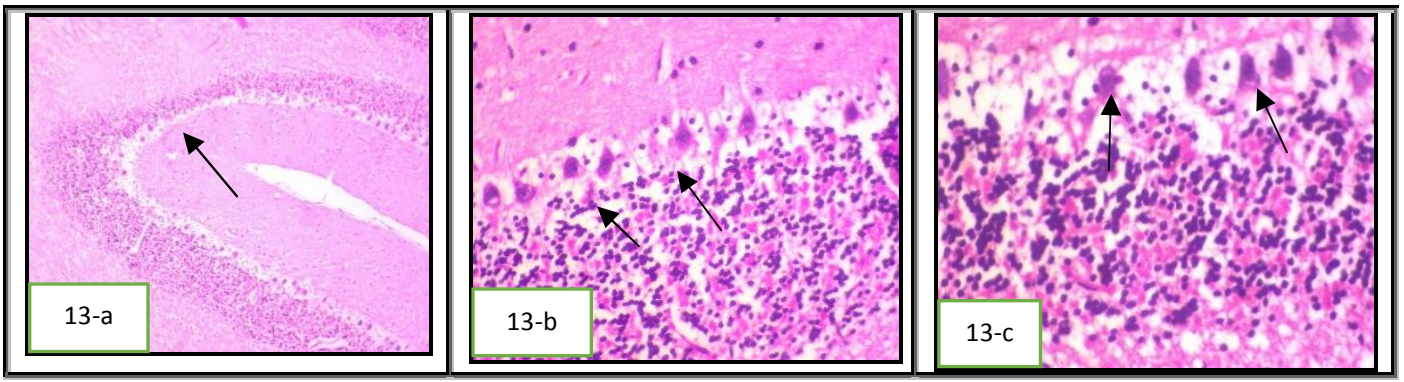

Fig. (13): Photomicrograph of hippocampus tissue section at 24hs showing: (a) Reduction granular cell layer number (arrow) [x100] (b) Autolysis of cells with nucleolar pyknotic nuclei (arrow) [x200] (c) Purkinje cells showed different changes such as contractile eosinophilic cytoplasm with blurred dark nuclei (arrow) [x400].
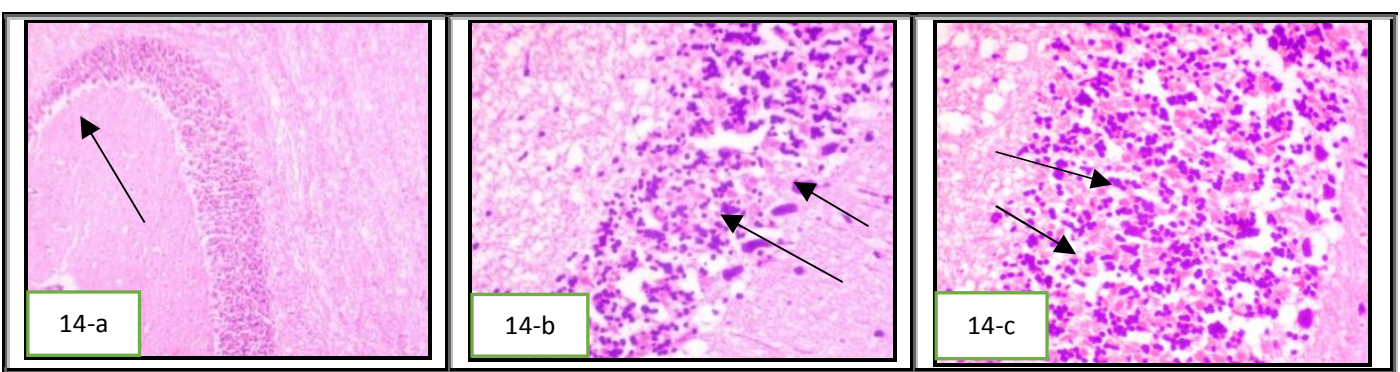

Fig. (14): Photomicrograph of hippocampus tissue section at 48hs showing: (a) Distinct reduction of granular cells number (arrow) [x100] (b) Lysis pyramidal cell layer (arrow) [x200] (c) Very small patches with one or two intact granular layers (arrow) [x400]. (H\&E)

\section{Discussion}

The degree of autolysis and putrefaction plays an important role establishing the time of death. Firstly, four minutes after death, the cells and body organs undergo breakdown by the intracellular enzymes that is known as autolysis (Di Maio \& Di Maio, 2000). Autolysis starts early in the tissues containing digestive and catalytic enzymes such as the adrenal gland (Dix \& Graham, 2000) and tissues with a low conjunctive matrix such as brain. It has been reported that the brain is the most suitable organ for estimation of time passed since death because it is well secluded by the skull and the brain mRNA transcripts are more stable than other organs (Ervin et al., 2007 and Liu et al., 2011).

Postmortem, severe nuclear disturbances occur; karyorrhexis, karyolysis and pyknosis; which finally disappear. The cytoplasm becomes acidophilic and appears as granular opaque mass (Kumar et al., 2015).

Caspase- 3 is the most common cysteine protease included in apoptosis and is considered the main executioner caspases. This protein is known as a "molecular switch" (Fan et al., 2014). In the present study, RT-PCR of caspase3 revealed significant increases in the mean mRNA expression levels of caspase- 3 till $24 \mathrm{hrs}$ after death then a significant reduction occurred at $48 \mathrm{hrs}$. Regarding to the correlation between caspase-3 mRNA expression levels and 
postmortem period, a significant moderate positive correlation was revealed.

Previous research has reported that the stability of RNA could be continued several days after death according to the tissue or even due to the process of death itself (Bauer, 2007). Caspase- 3 undergoes activation by Caspase-8, which is responsible for activation of the cell death. Occasionally, the Caspase- 8 signal is not sufficient to provoke cell death; hence, stimulation of the intrinsicmitochondrial pathway of apoptosis occurred with the liberation of cytochrome $\mathrm{c}$, which is responsible for formation of the apoptosome with procaspase 9. Finally, Caspase-3 is activated by Caspase-9, leading to cell death (Kavurma and Khachigian, 2003). It has been reported that there is no large destruction of mRNA in tissues after death until 36 hours (Marchuk et al., 1998).

Saber and Ali (2016) showed a strong positive linear correlation between mRNA levels of Caspase-3 in the gastrocnemius muscle with time passed since death. They found a raise in mRNA levels of caspase- 3 began $2 \mathrm{~h}$ postmortem until $6 \mathrm{~h}$ then a marked reduction occurred at $8 \mathrm{~h}$. Lee et al. (2016) has been reported that caspase-3 was completely degraded $84-96 \mathrm{~h}$ post-mortem $\left(\mathrm{PMI}_{50}\right.$ value $\left.=26.3 \mathrm{~h}\right)$ in kidney by western blot and $76 \%$ of the stained area for caspase- 3 was reduced gradually $48 \mathrm{~h}$ after death and totally absent at $96 \mathrm{~h}$ after death by immunohistochemistry. In another study, caspase levels started to decrease after $32 \mathrm{~h}$ post-mortem (Kemp et al., 2010). These differences may be due to different techniques and/or different tissue used in the studies. Inoue et al. (2002) found that the stability of mRNA is different among body organs.

IL-1 $\beta$ is one of the proinflammtory cytokines. Our findings showed that the brain and adrenal gland IL-1 $\beta$ mRNA mean expression levels reduced gradually with a significant strong negative correlation with the postmortem period. Previous studies have revealed a significant decrease of individual mRNA transcripts by increasing the postmortem period (Barrachina et al., 2006; Durrenberger et al., 2010 and Birdsill et al., 2011). This reduction may be due to starting of the autolysis process which resulting in the degradation of RNA after death by ribonucleases (Nagy et al., 2015) and/or by other environmental factors such as humidity and ultraviolet light (Bauer, 2007). In corroboration with our results, Inoue et al. (2002) have reported that IL-1 $\beta$ mRNA decreased with increasing the postmortem interval and could be detected 3 days after death from the dead body by RT-PCR.

Heinrich et al. (2007) have reported that postmortem mRNA degradation is variable and it is a complicated process, and the use of a single gene expression for estimation of postmortem interval may lead to invalid data.

In this study, the histopathological examination of adrenal gland revealed that postmortem changes in the adrenal medulla appeared earlier than in the adrenal cortex at 12 $\mathrm{hr}$ postmortem; with a marked expansion and pyknotic nuclei were observed. While, at $24 \mathrm{hr}$ an expansion of the adrenal cortex and a reduction of medulla were clear with no demarcation between different zonal cells. Blood sinusoids started dilatation at $6 \mathrm{hr}$, become moderate at $12 \mathrm{hr}$, and severe at $24 \mathrm{hr}$ then ruptured at $48 \mathrm{hr}$. At $48 \mathrm{hr}$, the adrenal tissue showed cellular shrinkage and dissociation, cytoplasmic acidophilia and finally karyolysis. While, karyorrhexis was not clear in the cortical and medullary cells. The results of the present study revealed that the adrenal glands could be helpful for histopathological examination before $48 \mathrm{hr}$ at $20^{\circ} \mathrm{C}$.

Elgawish et al. (2016) has recorded the postmortem changes in adrenal gland at $0,6,12$ hours. They revealed a marked expansion of the adrenal cortex and a reduction of the adrenal 
medulla at $12 \mathrm{~h}$. Pyknotic and vesicular nuclei were observed at 6 and $12 \mathrm{~h}$. Moderate to marked dilatation of blood sinusoids were seen at $12 \mathrm{~h}$. additionally, they observed a reduction of the adrenal medulla together with the time passed since death. Kurtulus et al. (2012) explained that the increase of the adrenal gland size as a result of diffuse intracytoplasmic vacuolar degenerative change and a widespread edema in the adrenal cortex and medulla. Moreover, they noticed nuclear alterations, such as, pyknosis, karyolysis and karyorrhexis.

On the other side, the histopathological examination of the brain, in the current study, revealed that the earliest postmortem changes appeared after $6 \mathrm{hr}$ in the cerebellum with mild decrease in the number of granular cell layer of hippocampus. At $12 \mathrm{hr}$, Loss of the nuclei and diffuse pallor were seen with no significant histopathologic changes were observed. While, at $24 \mathrm{hr}$, autolysis of cells with nucleolar pyknotic nuclei and shrunken eosinophilic cytoplasm became clear. Finally, at $48 \mathrm{hr}$, a reduction of granular cells number and size with intercellular oedema and pyramidal cell layer lysis were seen. The current study revealed that the brain tissue especially hippocampus could be helpful for histopathological examination before $12 \mathrm{hr}$ at $20^{\circ} \mathrm{C}$.

Sheleg et al. (2008) has recorded the autolytic changes in the brains of adult rats for 24 hours after cardiac arrest at $+20^{\circ} \mathrm{C}$. They revealed no significant histological alterations of the cortical, hippocampal, and cerebellar neurons during the period of the experiment by H\&E staining, while, the autolytic damages of the neurons started to appear at 12 hours after death by electron microscopy. Ujihira et al. (1993) found prominent autolytic changes in different parts of the brain with pale cytoplasm of neurons.

\section{Conclusion}

In conclusion, the biochemical and histopathological changes of the brain and the adrenal gland could be helpful for forensic experts in determining the postmortem intervals. Finally, as a result of variable stability of postmortem mRNA, it is recommendable to study multiple gene expressions in different body organs over several days postmortem to avoid misinterpretation of the data.

\section{Acknowledgment}

The authors thank Prof. Dr. Ahmed Hassan Osman, Pathology Department, Cairo University for his efficient assistance and great effort in the histopathological study in this work.

\section{References}

Bancroft, J.D.; Stevans, A. and Turner, D.R. (2008): The hematoxylins and eosin. In: Theory and Practice of Histological Techniques, $6^{\text {th }}$ Edition. M. Gamble (Ed.), Churchill Livingstone, Edinburgh, London, Melbourne, New York, P.P. 121-134.

Barrachina, M.; Castano, E. and Ferrer, I. (2006): "TaqMan PCR assay in the control of RNA normalization in human postmortem brain tissue". Neurochem. Int., 49:276-284.

Bauer, M. (2007): "RNA in forensic science". Forensic Sci. Int. Genet.,1:69-74.

Birdsill, A.C.; Walker, D.G.; Lue, L.; Sue, L.I. and Beach, T.G. (2011): "Postmortem interval effect on RNA and gene expression in human brain tissue". Cell Tissue Bank, 12:311-318. 
Di Maio, V. and Di Maio, D. (2000): Forensic Pathology, $2^{\text {nd }}$ Edition. CRC Pres LLC, P.P. 1-50.

Dix, J. and Graham, M. (2000): Time of Death, Decomposition and Identification an Atlas. CRC Pres LLC, P.P. 7-16.

Durrenberger, P.F.; Fernando, S.; Kashefi, S.N.; et al. (2010): "Effects of antemortem and postmortem variables on human brain mRNA quality: a brain net Europe study". J. Neuropathol. Exp. Neurol., 69:70-81.

Elgawish, R.R.; Abdelrazek, H.M.A. and Ghanem M. (2016): "Postmortem changes in electrolytes and adrenal gland at different intervals in adult male rats". A.J.A.V.S., 2:15-22.

Ervin, J.F.; Heinzen, E.L.; Cronin, K.D.; et al. (2007): "Postmortem delay has minimal effect on brain RNA integrity". J. Neuropathol. Exp. Neurol., 66:1093-1099.

Fan, W.; Dai, Y.; Xu, H.; et al. (2014): "Caspase-3 modulates regenerative response after stroke". Stem Cells, 32(2):473-486.

Gomaa, M.S.; Abd El-Khalek, A.M. and Sameer, M.M. (2013): "The relationship between the postmortem interval and the DNA degradation in brain and liver of adult albino rats". J. Am. Sci., 9:535-540.

Heinrich, M.; Lutz-Bonengel, S.; Matt, K. and Schmidt. U. (2007): "Real-time PCR detection of five different "endogenous control gene" transcripts in forensic autopsy material". Forensic Sci. Int. Genet., 1:163-169.

Henssge, C. and Madea, B. (2007): "Estimation of the time since death". Forensic Sci. Int., 165: 182-184.
Hostiuc, S.; Rusu, M.C.; Mănoiu, V.S.; et al. (2017): "Usefulness of ultrastructure studies for the estimation of the postmortem interval. A systematic review". Rom. J. Morphol. Embryol., 58:377-384.

Inoue, H.; Kimura, A. and Tuji, T. (2002): "Degradation profile of mRNA in a dead rat body: basic semi-quantification study". Forensic Sci Int., 130:127-132.

Kavurma, M.M. and Khachigian, L.M. (2003): "Signaling and transcriptional control of fas ligand gene expression." Cell Death Differ., 10:36-44.

Kemp, C.M.; Sensky, P.L.; Bardsley, R.G.; Buttery, P.J. and Parr, T. (2010): "Tenderness-an enzymatic view". Meat Sci. 84:248-256.

Kumar, V.; Abbas, A. and Aster, J.C. (2015): Cellular responses to stress and toxic insults: adaptation, injury and death. In: Robbins and Cotran Pathologic Basis of Disease, $9^{\text {th }}$ Edition. Elsevier Saunders, Canada, P.P. 13-69.

Kurtulus, A.; Acar, K.; Sorkun, H.; Kelten, C. and Boz, B. (2012): "The relationship between adrenal gland morphometric changes and postmortem interval in rats: A stereological study". Leg. Med., 14:214-218.

Lee, D.G.; Yang, K.E.; Hwang, J.W.; et al. (2016): "Degradation of kidney and psoas muscle proteins as indicators of postmortem interval in a rat model, with use of lateral flow technology". PLoS One. 23;11(8):e0160557.

Liu, Y.L.; Ma, K.J.; Li, W.C.; et al. (2011): "Estimation of early postmortem interval using beta-actin mRNA in rat's brain, heart and kidney". Fa Yi Xue Za Zhi, 27:5-8. 
Lv, Y.H.; Ma, J.L.; Pan, H.; et al. (2016): "RNA degradation as described by a mathematical model for postmortem interval determination". J. Forensic Legal Med., 44:43-52.

Madea, B. (2005): "Is there recent progress in the estimation of the postmortem interval by means of thanatochemistry?" Forensic Sci. Int., 151: 139-149.

Marchuk, L.; Sciore, P.; Reno, C.; Frank, C.B. and Hart, D.A. (1998): "Postmortem stability of total RNA is olated from rabbit ligament, tendon and cartilage". Biochim. Biophys. Acta., 1379:171-177.

Monoranu, C.M.; Apfelbacher, M.; Grunblatt, E.; et al. (2009): " $\mathrm{pH}$ measurement as quality control on human post mortem brain tissue: a study of the BrainNet Europe consortium". Neuropathol. Appl. Neurobiol., 35:329-337.

Nagy, C.; Maheu, M.; Lopez, J.P.; et al. (2015): "Effects of Postmortem Interval on Biomolecule Integrity in the Brain". J. Neuropathol. Exp. Neurol., 74: 459-469.

Pfaffl, M.W. (2004): Quantification strategies in real-time PCR. In: Bustin, S.A. (Eds), A-Z of quantitative PCR. International University Line, San Diego, P.P. 78-112.

Prahlow, J.A. (2010): Introduction to forensic sciences. In: Forensic Pathology for Police, Death Investigators, Attorneys, and Forensic Scientists. Springer Science Business Media LLC, P.P. 17-33.
Saber, T.M. and Ali, H.A. (2016): "Expression of cell death genes estimates time since death in rats". Rom. J. Leg. Med., 24:164-167.

Sampaio-Silva, F.; Magalha es, T.; Carvalho, F.; Dinis-Oliveira, R.J. and Silvestre, R. (2013): "Profiling of RNA degradation for estimation of post morterm interval". PLoS ONE, 8: e56507. doi:10.1371/journal.pone. 0056507.

Sheedy, D.; Harding, A.; Say, M.; Stevens, J. and Kril J.J. (2012): "Histological assessment of cerebellar granule cell layer in postmortem brain; a useful marker of tissue integrity" Cell Tissue Bank, 13: 521-527.

Sheleg, S.V.; Lobello, J.R.; Hixon, H.; et al. (2008): "Stability and autolysis of cortical neurons in post-mortem adult rat brains." Int. J. Clin. Exp. Pathol., 1:291-299.

Ujihira, N.; Hashizume, Y. and Takahashi, A. (1993): "A clinico-neuropathological study on brain death". Nagoya J. Med. Sci., 56:89-99.

VanGuilder, H.D.; Vrana, K.E. and Freeman, W.M. (2008): "Twenty-five years of quantitative PCR for gene expression analysis". Biotechniques., 44:619-626.

Vass, A.A.; Barshick, S.; Sega, G.; et al. (2002): "Decomposition chemistry of human remains: a new methodology for determining the postmortem interval". J. Forensic Sci., 47:542-553.

Wen-Can, L.; Kai-Jun, M.; Ye-Hui, L.; et al. (2014): "Postmortem interval determination using 18S-rRNA and microRNA". Sci. Justice, 54:307-310. 


\section{تحديد الفترة التي مضت على الوفاة من تكسير رسول الحمض النووي والتفيرات

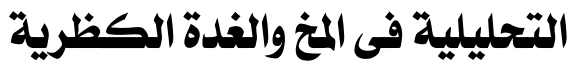

\section{داليا محمد على'، أسامه أ. حسز'، ماجى م. رمزى'، نجوى م. زينهه}

'قسم الطب الثرعى والسموم الاكلينيكية، ` قسم الكيمياء الحيوية، كلية الطب البشرى، جامعة المنيا، مصر

يعد تقدير الفترة التي مضت على الوفاة مهم جدا لخبر اء الطب الشرعي خاصـة في القضايا الجنائيـة.

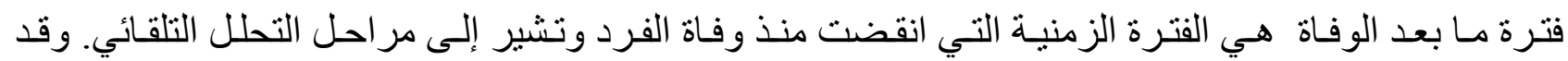
هدفت هذه الدر اسة إلى تقدير فترة ما بعد الوفاة من تعبير رسول الحمض النووى لـلكاسبيس بّ و الانترلوكين

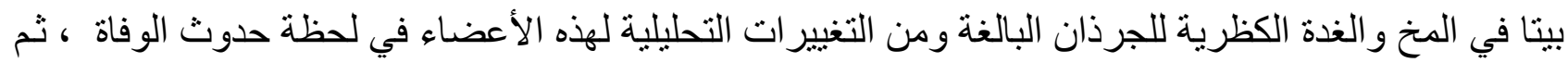

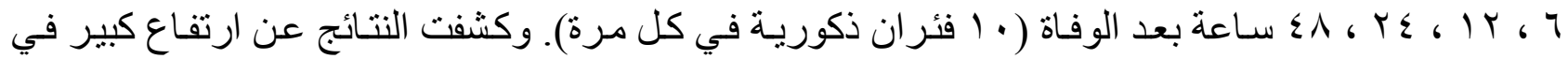

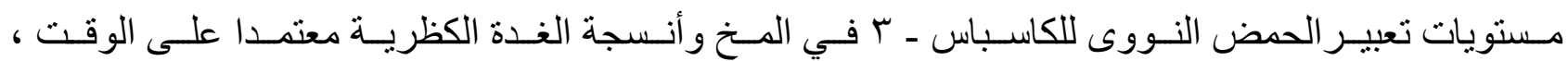

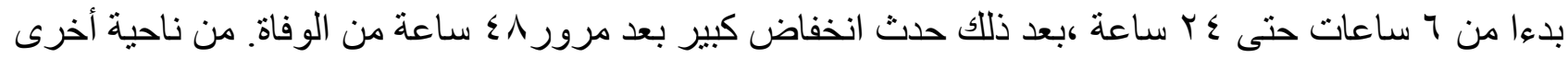

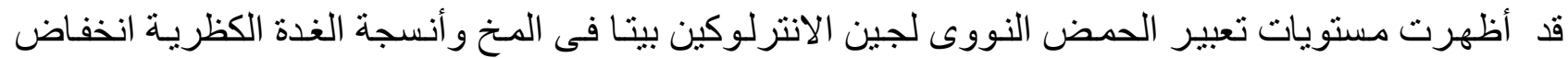

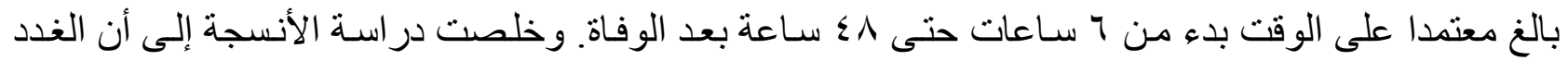

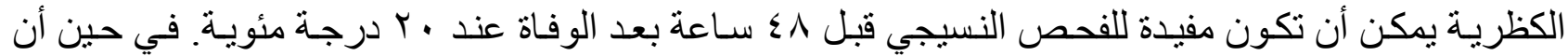

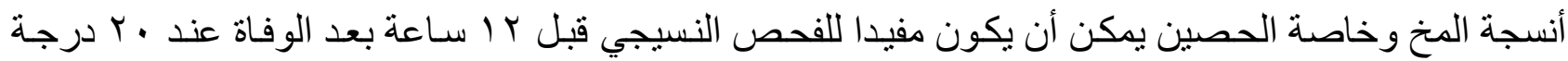

